\title{
Lessons from the financial crisis: funded pension funds should invest conservatively
}

Citation for published version (APA):

Muysken, J., \& Sleijpen, O. C. H. M. (2011). Lessons from the financial crisis: funded pension funds should invest conservatively. METEOR, Maastricht University School of Business and Economics. METEOR Research Memorandum No. 020 https://doi.org/10.26481/umamet.2011020

Document status and date:

Published: 01/01/2011

DOI:

10.26481/umamet.2011020

Document Version:

Publisher's PDF, also known as Version of record

\section{Please check the document version of this publication:}

- A submitted manuscript is the version of the article upon submission and before peer-review. There can be important differences between the submitted version and the official published version of record.

People interested in the research are advised to contact the author for the final version of the publication, or visit the DOI to the publisher's website.

- The final author version and the galley proof are versions of the publication after peer review.

- The final published version features the final layout of the paper including the volume, issue and page numbers.

Link to publication

\footnotetext{
General rights rights.

- You may freely distribute the URL identifying the publication in the public portal. please follow below link for the End User Agreement:

www.umlib.nl/taverne-license

Take down policy

If you believe that this document breaches copyright please contact us at:

repository@maastrichtuniversity.nl

providing details and we will investigate your claim.
}

Copyright and moral rights for the publications made accessible in the public portal are retained by the authors and/or other copyright owners and it is a condition of accessing publications that users recognise and abide by the legal requirements associated with these

- Users may download and print one copy of any publication from the public portal for the purpose of private study or research.

- You may not further distribute the material or use it for any profit-making activity or commercial gain

If the publication is distributed under the terms of Article $25 \mathrm{fa}$ of the Dutch Copyright Act, indicated by the "Taverne" license above, 
Caicai Du, Joan Muysken, Olaf Sleijpen

Lessons from the financial crisis: Funded pension funds should invest conservatively

$\mathrm{RM} / 11 / 020$

\section{METEOR}

Maastricht University School of Business and Economics Maastricht Research School of Economics

of Technology and Organization

\section{PO. Box 616}

NL - 6200 MD Maastricht

The Netherlands 


\title{
Lessons from the financial crisis: \\ Funded pension funds should invest conservatively
}

\author{
Cai Cai $\mathrm{Du}^{1}$ \\ Joan Muysken \\ Olaf Sleijpen \\ Department of Economics, SBE \\ Maastricht University \\ The Netherlands
}

February 2011

\begin{abstract}
We model a three-pillar pension system and analyse in this context the impact of the financial crisis on the aggregate economy, using an overlapping generations model where individuals live for two periods. The system consists of (1) a PAYG pension system, (2) a Defined Benefit pension fund, and (3) private savings. We show that in this pension system the impact of the financial crisis on the economy is mitigated in case the funded pension funds have invested in more risk averse assets and savings are invested in more risky assets. In order to illustrate the working of the model with respect to the impact of the financial crisis, both in terms of size and development over time, we provide simulation results for the Netherlands. We argue that the lesson from the financial crisis is that pension funds should always invest in relatively risk-free assets, while private savings can be invested in more risky assets.
\end{abstract}

\footnotetext{
${ }^{1}$ Corresponding author: Tel: 0031 643029504; Email address: C.Du@maastrichtuniversity.nl
} 


\section{Introduction}

The Dutch pension system is quite renowned for its well-developed three-pillar structure. The advantage in a macroeconomic context is that it hedges against different macroeconomic risks (Du, Muysken and Sleijpen, 2010). The first pillar (state) pensions, financed on a pay-as-yougo basis, help in providing basic old-age benefits and are not very vulnerable to inflation. The second and third pillars, financed by collective and individual savings, respectively, supposedly provide a better hedge against an ageing society, but are susceptible to inflationary and asset price developments.

Since the 1990s, pension funds, which traditionally invested in secure assets only, like government bonds, increasingly expanded their portfolio towards more risky assets, among other things triggered by the increase in stock prices in this period. However, the dot-com crisis in 2001 and in particular the recent financial crisis revealed the danger of this strategy for the viability of funded pension funds and raised the question to what extent the system provides enough guarantees against risks.

In Du, Muysken and Sleijpen (2010) we develop a simple overlapping generations model which analyses how in case of defined benefits the three pillars relate to different exogenous (economic) shocks when second pillar pension funds invest in risky assets (equity) and individuals (third pillar) invest in secure assets (bonds). ${ }^{2}$ When simulating the model, it appears that a stock market crisis leads to strong increases in contribution rates to the pension fund and negatively affects economic growth.

In this paper we compare the three-pillar pension system under two different designs. One is a system where the pension fund (second pillar) invests in equity and households (third pillar) invest in bonds. The other is a system where the pension fund and households invest in bonds and equity, respectively. The aim of our paper is to demonstrate the effect of a different investment strategy of pension funds and households when facing a stock market shock.

We show that in case of a fall in equity returns, consumption of both young and old generations is higher when pensions are invested in risk-free assets and private savings are invested in risky assets, when compared to a situation in which the opposite investment strategy is followed. Savings are higher too. An interesting observation is that in the case of an increase in equity returns the opposite effect does not hold: in particular consumption of

\footnotetext{
${ }^{2}$ A somewhat similar model is presented in Beetsma and Bovenberg (2008), albeit in a closed economy context. They only analyse a two-period model and their analysis finishes with the second young generation. As a consequence the second young generation bears very high costs in a defined benefit system, which biases their analysis against that system. Moreover, their model does not allow for continuous time simulations.
} 
the young is lower during a stock market boom, when pensions are invested in risk-free assets and private savings are invested in risky assets. As a consequence we argue that pension funds should always invest in relatively risk-free assets, while private savings then can be invested in more risky assets.

Our focus is quite different compared to the previous literature on investment strategies of pension funds. Gollier (2007) sets operational rules for a pension fund to optimize both the sharing of risk across generations and the dynamic portfolio management of this fund and estimates the welfare gain of intergenerational risk sharing. The focus is on the intergenerational risk sharing of the pension fund. Maurer, Mitchell and Rogalla (2009) analyze the risks and rewards of moving from an unfunded defined benefit pension system to a funded plan for German civil servants, allowing for alternative strategic contribution and investment patterns. Their results show that moving towards a funded public pension system can be beneficial for both civil servants and taxpayers. Thus the focus is on the gain of the transfer from an unfunded pension system to a funded one. Matsen and Thogersen (2004) study the optimal size of the pay-as-you-go system as well as the optimal split between funded and unfunded pension savings by means of a theoretical portfolio choice framework. Duttaa, Kapurb and Orszag (2000) analyze the optimal pension funding choice in a meanvariance portfolio choice framework. The optimum funding solution then is to hedge by holding a diversified set of liabilities, both funded and unfunded. They also look at what portfolio of bonds and equities should be held in a funded system. Miles (2000) uses stochastic simulations of calibrated models to assess the optimal degree of reliance on funded pensions and on a particular type of unfunded (PAYG) pension. He estimates how the optimal level of unfunded state pensions depends on the rate of return and income risks and also upon the actuarial fairness of annuity contracts. Knell (2010) studies the optimal portfolio mix between funded and unfunded pension systems when people care about relative consumption. Burtless (2010) points out that the recent financial crisis and the historical record present important lessons on the design of national pension systems. First, wide fluctuations in asset returns make it hard for well-informed savers to select a savings rate or a sensible investment strategy for defined-contribution (DC) pensions. Second, it is hard for ordinary workers, as opposed to financial professionals, to make sensible choices about portfolio allocation. All these papers focus on the design of the funded pension system, but ignore the impact of financial calamities on the distributional effects between generations in relation to the risk-taking nature of funded pensions. That is the focus of our paper. 
The paper is organised as follows. In Section 2 our model of an open economy, consisting of two overlapping generations with a three-pillar pension system and defined benefits, is presented. Section 3 presents the steady state solution of the model and analyses the impact of different exogenous shocks. In particular, the impact of a shock in returns on financial assets (bonds and equity) is considered. We also show the impact of changes in the variance of the equity return. Section 4 presents a calibration of the model, based on data for the Netherlands. Moreover, the impact of stock market shocks is simulated, focusing on a decrease in stock prices comparable to that of the 2008 financial crisis, as well as the impact of a boom in the stock market. We show that a recession and a boom have an asymmetric impact on consumption between both generations. Section 5 concludes.

\section{The model}

The model consists of firms, consumers in two overlapping generations, a public sector and a pension fund. Firms operate under full competition and maximise profits. The inputs are labour and capital. The return on capital is exogenously given, assuming a small open economy. The wage costs are the sum of the wage received by the workers and the pension contribution paid by the firm.

Consumers live two periods. In the first period, individuals supply labour and earn a wage income at an exogenous participation rate. In the second period, only part of the individuals survive. The survivors are retired and receive pensions from the public sector (first pillar) and the pension fund (second pillar). Consumers aim to maximise their lifetime utility by choosing savings in the first period (third pillar). They invest their savings in equities and bonds.

The public sector taxes the workers in order to pay public pensions to all retired individuals proportional to the current wage rate. The public pension scheme is of a PAYG (pay-as-you-go)type. The pension fund receives contributions from the firms and the workers, and pays pensions to the retired workers proportional to the previous wage rate.

The pension fund invests wealth in equities and bonds. The workers are obliged to participate in the fund. Since we assume defined benefits, ${ }^{3}$ the pension benefits are not directly related to asset market rates of return; shocks to the pension wealth are absorbed by the contribution rate (except under extreme situations).

\footnotetext{
${ }^{3}$ DNB (2010) published results from their household survey which show that a large majority of workers in the Netherlands is willing to pay "considerably higher pension premiums" in order to maintain defined beneifits.
} 


\section{$2.1 \quad$ Firms}

Firms use labour $L_{t}$ and capital $K_{t}$ to produce output $Y_{t}$, according to a Cobb-Douglas production function:

$Y_{t}=A_{t} K_{t}^{\alpha} L_{t}^{1-\alpha}$

Here $A_{t}$ measures the productivity level, which grows at a rate $g$.

Firm behaviour is based on profit maximisation. This yields:

$w_{t}^{c}=w_{t}\left(1+\beta \tau_{t}^{p}\right)=(1-\alpha) A_{t} K_{t}^{\alpha} L_{t}^{-\alpha}$

$r_{t}^{k}=\alpha A_{t} K_{t}^{\alpha-1} L_{t}^{1-\alpha}$

Real wage cost $w_{t}^{c}$ consist of the real wage $w_{t}$, received by the workers, and the share $\beta$ $(0 \leq \beta \leq 1)$ of the real pension contribution $\tau_{t}^{p}$, which is paid by the employer. We assume a small open economy, which implies that the real rate of capital return is determined on the world market - hence $r_{t}^{k}$ is given. Finally employment $L_{t}$ is equal to the exogenous participation of the young individuals, $p N_{t}-$ we elaborate the latter below.

Equations (2) and (3) can be combined to yield an expression of the capital stock and the wage rate in terms of exogenous variables:

$$
\begin{aligned}
& K_{t}=\left(A_{t} \frac{\alpha}{r_{t}^{k}}\right)^{\frac{1}{1-\alpha}} p N_{t} \\
& w_{t}=(1-\alpha) A_{t}^{\frac{1}{1-\alpha}}\left(\frac{\alpha}{r_{t}^{k}}\right)^{\frac{\alpha}{1-\alpha}} \frac{1}{1+\beta \tau_{t}^{p}}
\end{aligned}
$$

\subsection{Consumers}

We assume an overlapping generation model with two generations: young and old. There are $N_{t}$ young individuals, who participate in the labour market at a rate $p(0<p \leq 1)$. The 
growth rate of $N_{t}$ is $n$. All participating young individuals earn a real wage income $w_{t}$, from which they contribute to the public sector benefits and the pension fund at rates $\tau_{t}^{g}$ and $(1-\beta) \tau_{t}^{p}$, respectively. Net income then is spent on consumption and savings. The savings are invested in bonds and equities.

Only a fraction $\varepsilon$ of young individuals survives to the next period. During that period the individuals are old and at the end of that period they die. An increase in the fraction $\varepsilon$ can be used to mimic the process of ageing. When old, the individuals do not work, but receive a public pension $\eta_{t}^{g}$ and a pension $\eta_{t}^{p}$ from the pension fund ${ }^{4}$ Moreover, they use the returns on their savings, as well as the savings themselves, to finance consumption in retirement. The individuals therefore face the following real budget constraints in their two periods of life:

$$
\begin{aligned}
& c_{t}^{y}=\left[1-\tau_{t}^{g}-(1-\beta) \tau_{t}^{p}\right] p_{t} w_{t}-s_{t} \\
& c_{t+1}^{o}=\frac{1+r_{t+1}^{c o n s}}{\varepsilon} s_{t}+\eta_{t+1}^{g}+\eta_{t+1}^{p}
\end{aligned}
$$

Here $c_{t}^{y}\left(c_{t+1}^{o}\right)$ is the consumption of the young (old) and $s_{t}$ is savings. The savings earn an expected real return $r_{t}^{\text {cons }}$, with $1+r_{t}^{c o n s}=\frac{\left(1+r_{t}^{x c}\right)\left(1+\pi_{t}^{e}\right)}{\left(1+\pi_{t}\right)}$. Here $r_{t}^{x c}=\lambda^{\text {cons }} r_{t}^{b}+\left(1-\lambda^{\text {cons }}\right) r_{t}^{e}$. $\lambda^{\text {cons }}$ is the proportion of the savings invested in bonds. $\left(1-\lambda^{\text {cons }}\right)$ is the proportion of the savings invested in equities. $\pi_{t}^{e}$ is the expected inflation rate and $\pi_{t}$ is the actual inflation rate. Because only a fraction $\varepsilon$ of individuals survives to the next period, the assets of those who decease fall to surviving contemporaries. The total real return on savings then is $\frac{1+r_{t}^{\text {cons }}}{\varepsilon}-1$.

The pension from the pension fund is a fraction $\xi^{p}$ of the past wage. It should also be corrected for the participation rate in the young period, to allow for consumption by all old consumers (including those who did not fully participate when young). Moreover, the pension fund fully compensates the effect of inflation on the pension. Thus we find:

$$
\eta_{t+1}^{p}=\xi^{p} p w_{t}
$$

\footnotetext{
${ }^{4}$ Actually, only those who have worked when young receive a pension, but in our aggregate analysis we take that into account by including the participation rate in equation (8).
} 
The public pension is a fraction $\xi^{g}$ of the current wage (in order to relate it to the wage in the previous period we use the fact that the real wage grows with productivity growth $g$ ), hence:

$\eta_{t+1}^{g}=\xi^{g} w_{t+1}=\xi^{g} w_{t}(1+g)$

Given the budget constraints (6) and (7), the individuals maximise their expected lifetime utility represented by

$E U_{t}=\frac{\left(c_{t}^{y}\right)^{1-\theta}}{1-\theta}+\gamma \varepsilon \frac{\left(c_{t+1}^{o}\right)^{1-\theta}}{1-\theta}$

where $\gamma$ measures the rate of time preference of the individual and $1 / \theta>0$ is the elasticity of intertemporal substitution. Maximising equation (10) subject to the budget constraints results in the following first-order condition

$$
\frac{c_{t+1}^{o}}{c_{t}^{y}}=\left[\gamma\left(1+r_{t+1}^{c o n s}\right)\right]^{\frac{1}{\theta}}
$$

Combing equations (6) and (7) with equation (11) gives the following individual consumption and saving functions:

$c_{t}^{y}=\Lambda_{t} w_{t}$

$c_{t+1}^{o}=\left(\gamma\left(1+r_{t+1}^{c o n s}\right)\right)^{\frac{1}{\theta}} \Lambda_{t} w_{t}$

$s_{t}=\left\{\left[1-\tau_{t}^{g}-(1-\beta) \tau_{t}^{p}\right] p-\Lambda_{t}\right\} w_{t}$

Where $\Lambda_{t}=\frac{\left(1+r_{t+1}^{c o n s}\right)\left[1-\tau_{t}^{g}-(1-\beta) \tau_{t}^{p}\right] p+\varepsilon\left[\xi^{p} p+\xi^{g}(1+g)\right]}{1}$ and the wage rate is given by $\varepsilon\left(\gamma\left(1+r_{t+1}^{\text {cons }}\right)\right)^{\frac{1}{\theta}}+\left(1+r_{t+1}^{c o n s}\right)$

equation (5).

2.3 The public sector 
The public sector receives taxes from the workers for paying the pension benefits $\eta_{t+1}^{g}$ to the retirees according to equation (9). The pension scheme is of a PAYG nature. Hence, the real budget constraint of the public sector is given by:

$\varepsilon \eta_{t+1}^{g}=\tau_{t+1}^{g}(1+n) p w_{t+1}$

Substituting equation (9) then yields:

$\tau_{t+1}^{g}=\frac{\varepsilon \xi^{g}}{(1+n) p}$

This shows that the contribution rate of the PAYG system decreases with increases in population growth and the participation rate, whereas it increases with ageing and a higher benefit.

\subsection{The pension fund}

The pension fund has real financial wealth $W_{t}^{p}$ at the start of a period, it receives contributions $\tau_{t}^{p} p w_{t}$ from firms and workers and pays pension benefits $\eta_{t}^{p}$ to retirees according to equation (8). The fund invests all its wealth in bonds and equities which yield an

expected real return $r_{t}^{p f}$, with $1+r_{t}^{p f}=\frac{\left(1+r_{t}^{x p}\right)\left(1+\pi_{t}^{e}\right)}{1+\pi_{t}}$, depending on the investment strategy of the pension fund. $r_{t}^{x p}=\lambda^{p f} r_{t}^{b}+\left(1-\lambda^{p f}\right) r_{t}^{e} \cdot \lambda^{p f}$ is the proportion of the wealth invested in bonds. $\left(1-\lambda^{p f}\right)$ is the proportion of the wealth invested in equities. Thus the pension fund real wealth accumulates according to:

$W_{t+1}^{p}=\left(1+r_{t+1}^{p f}\right)\left(W_{t}^{p}+\tau_{t}^{p} N_{t} p w_{t}-\varepsilon N_{t-1} \eta_{t}^{p}\right)$

The pension fund wants to equals its wealth to its liability - the latter equals $\varepsilon N_{t-1} \eta_{t}^{p}$ in the steady state. The pension fund will adjust its contribution rate when the accumulated wealth does not meet its target value, such that the wealth accumulation is back to its target value in $1 / \varphi$ years. Hence: 
$W_{t+1}^{p}=\varepsilon N_{t} \eta_{t+1}^{p}-\varphi\left(W_{t}^{p}-\varepsilon N_{t-1} \eta_{t}^{p}\right)$

In the steady state, where the pension fund meets its liabilities, we have

$W_{t}^{p}=\varepsilon N_{t-1} \eta_{t}^{p}$

Assuming that in that situation expected inflation also equals actual inflation we find for the pension fund contribution rate $\tau_{t}^{p}$ from equations (8), (17) and (19):

$\tau_{t}^{p}=\frac{\varepsilon \xi^{p}}{1+r_{t}^{x p}}$

Equation (20) shows that in the steady state the contribution rate decreases with higher returns on assets and increases with ageing and a higher benefit.

In a situation where the pension fund does not meet its liabilities, we find combining equations (17) and (18):

$\tau_{t}^{p}=\frac{\varepsilon N_{t} \eta_{t+1}^{p}-\left(1+r_{t}^{p f}+\varphi\right)\left(W_{t}^{p}-\varepsilon N_{t-1} \eta_{t}^{p}\right)}{\left(1+r_{t}^{p f}\right) N_{t} p_{t} w_{t}}$

This converges to the steady state contribution rate (20) when the pension fund meets its liabilities and expected inflation also equals actual inflation. 


\subsection{The complete model}

The complete model is given by equations (5), (12) - (14), (16) and in the steady state equation (20). Assuming the steady state, we also have $r_{t}^{\text {cons }}=r_{t}^{x c}$. When we assume all rates of return, as well as the participation rate, to be constant over time, the model can be solved in a straightforward way. We elaborate this in the steady state solution in Section 3. This also allows us to analyse the impact of shocks to the economy in a comparative static context. To consider the properties of the model during the transition period in response to shocks we have to resort to simulations, since the dynamics of the model then become intractable analytically. The simulation results are presented in Section 4.

\section{The steady state}

In Section 3.1 we solve the model for the steady state. In the steady state, actual inflation equals expected inflation and the financial wealth of the pension fund is equal to its liabilities in every period. In Section 3.2 we investigate the comparative statics properties of the model by analysing the impact of exogenous shocks on the steady state solution. We focus in particular on the effect of the financial crisis in Section 3.3 under different scenarios for the diversification of risks between pension funds and private savings. Finally we look at the effect of the variance of equity return in Section 3.4.

\subsection{The steady state solution}

From the presentation of the model in the previous section it follows directly that the steady state is characterised by the following equations: ${ }^{5}$

$$
\begin{aligned}
& c^{y}=\Lambda w \\
& c^{o}=\left[\gamma\left(1+r^{x c}\right)\right]^{\frac{1}{\theta}} \Lambda w \\
& s=\left\{\left[1-\tau^{g}-(1-\beta) \tau^{p}\right] p-\Lambda\right\} w
\end{aligned}
$$

\footnotetext{
${ }^{5}$ We omit the time subscript of each variable, since it is not relevant in the steady-state.
} 
Where $\Lambda=\frac{\left(1+r^{x c}\right)\left[1-\tau^{g}-(1-\beta) \tau^{p}\right] p+\varepsilon\left[\xi^{p} p+\xi^{g}(1+g)\right]}{\varepsilon\left[\gamma\left(1+r^{x c}\right)\right]^{\frac{1}{\theta}}+\left(1+r^{x c}\right)}$

$w=(1-\alpha) A^{\frac{1}{1-\alpha}}\left(\frac{\alpha}{r^{k}}\right)^{\frac{\alpha}{1-\alpha}} \frac{1}{1+\beta \tau^{p}}$

$\tau^{g}=\frac{\varepsilon \xi^{g}}{(1+n) p}$

$\tau^{p}=\frac{\varepsilon \xi^{p}}{1+r^{x p}}$

When second pillar invests in equities $\left(\lambda^{p f}=0\right)$ and third pillar invests in bonds $\left(\lambda^{\text {cons }}=1\right)$, $r^{x p}=r^{e}, r^{x c}=r^{b}$. When second pillar invests in bonds and third pillar invests in equities, $r^{x c}=r^{e}, r^{x p}=r^{b}$.The variables on the left-hand side of equations (22) - (28) are the endogenous variables and the other variables $r^{b}, r^{e}, r^{k}$ and $p$ are exogenous.

From equations (27) and (28) one sees that the "return" on the PAYG contributions is given by (29a), ${ }^{6}$ while in a normal situation the "return" on the pension contributions is given by equation (29b). Finally we know from the discussion on consumer behaviour that the return on savings is given by $(29 \mathrm{c})$ :

$\frac{\xi^{g} w(1+g)}{\tau^{g} w}-1=\frac{(1+n)(1+g) p}{\varepsilon}-1$

$\frac{\xi^{p}}{\tau^{p}}-1=\frac{1+r^{x p}}{\varepsilon}-1$

$\frac{1+r^{x c}}{\varepsilon}-1$

The return on pension funds therefore is larger than that on public pensions as long as $1+r^{x p}>(1+n)(1+g) p$, and it exceeds that on private savings as long as $r^{x p}>r^{x c}$. By having a pension system which consists of three pillars, the pension is essentially spread over a portfolio with different rates of return, as equation (29) illustrates. One hedges against inflation and asset price risk by using a PAYG system; one hedges against demographic risk

\footnotetext{
${ }^{6}$ Individuals pay $\tau^{g} w$ in the young period and receive $\xi^{g} w(1+g)$ in the old period. Therefore, the return on the PAYG contributions is given by equation (29a).
} 
by using a pension fund, and one allows for individual risk preferences by using private savings next to a pension fund.

3.2 The impact of exogenous shocks on the steady state

The impact of shocks to pension benefits, returns of bonds and equity, the inflation rate, the participation rate, the survival rate and population growth on the endogenous variables of the model is summarised in Table $1\left[{ }^{7}\right.$ These results are elaborated and discussed in relation to the literature in Du, Muysken and Sleijpen (2010).

In Table 1 one also sees that the sufficient conditions for the negative response of the consumptions to the PAYG benefits and the pension fund benefits depend on the investment strategy of the pension system. The negative response of consumption of both the young and the old to the PAYG benefits depends on $\left(1+r^{x c}\right)>(1+g)(1+n)$. The reason is that the lifetime income, out of which consumption in both periods is financed, decreases when the return on savings $\left(1+r^{x c}\right)$ is higher than the return on the public pension contribution $(1+g)(1+n)-$ compare equations (29a) and $(29 c) \cdot{ }^{8}$ Moreover the return on savings depends on the savings invested in bonds or equities.

The negative response of consumption of both generations to the pension fund benefits depends on $\frac{1+r^{x p}}{1-\beta}<\left(1+r^{x c}\right)$. The reason is that the lifetime income, out of which consumption in both periods is financed, decreases when the return on savings $\left(1+r^{x c}\right)$ is higher than the return on the pension contribution $\frac{1+r^{x p}}{1-\beta}<\left(1+r^{x c}\right)-$ compare equations $(29 \mathrm{~b})$ and $\left(29 \mathrm{c} .{ }^{9}\right.$ Again the return on savings and the return on pension contribution depend on the investment strategy.

\footnotetext{
${ }^{7}$ In Du, Muysken and Sleijpen (2010; Appendix, section 1) the derivations and resulting conditions underlying Table 1 are presented.

${ }^{8}$ Because the participation rate is $p$, the return on the public pension contribution should be divided by $p$.

${ }^{9}$ Individuals only pay part of the pension premium so the return on the pension premium should be divided by $(1-\beta)$.
} 
Table 1 The impact of exogenous shocks on the economy

\begin{tabular}{|c|c|c|c|c|c|c|c|}
\hline & & & Contr & ion rates & & ption & Savings \\
\hline & & & PAYG & Pension & Young & Old & \\
\hline & & & $\tau^{g}$ & $\tau^{p}$ & $c^{y}$ & $c^{o}$ & $s$ \\
\hline PAYG b & nefits & $\xi^{g}$ & + & 0 & $-*$ & $-*$ & - \\
\hline Pension & enefits & $\xi^{p}$ & 0 & + & $-* *$ & $-* *$ & - \\
\hline Employ & contrib. & $\beta$ & 0 & 0 & $?$ & $?$ & $?$ \\
\hline Inflation & & $\pi=\pi^{e}$ & 0 & 0 & 0 & 0 & 0 \\
\hline & & $\pi \neq \pi^{e}$ & 0 & + & $?$ & - & - \\
\hline $\begin{array}{l}\text { Risk- } \\
\text { free } \\
\text { pension } \\
\text { fund }\end{array}$ & $\begin{array}{l}\text { Bonds } \\
\text { returns }\end{array}$ & $\begin{array}{l}r^{x p}=r^{b} \\
\left(\lambda^{p f}=1\right)\end{array}$ & 0 & - & + & + & + \\
\hline $\begin{array}{l}\text { and } \\
\text { risky } \\
\text { private } \\
\text { savings }\end{array}$ & $\begin{array}{l}\text { Equity } \\
\text { returns }\end{array}$ & $\begin{array}{l}r^{x c}=r^{e} \\
\left(\lambda^{c o n s}=0\right)\end{array}$ & 0 & 0 & $-* * *$ & $+* * *$ & $+* * *$ \\
\hline $\begin{array}{l}\text { Risk- } \\
\text { free } \\
\text { private }\end{array}$ & $\begin{array}{l}\text { Bonds } \\
\text { returns }\end{array}$ & $\begin{array}{l}r^{x c}=r^{b} \\
\left(\lambda^{c o n s}=1\right)\end{array}$ & 0 & 0 & $-* * *$ & $+* * *$ & $+* * *$ \\
\hline $\begin{array}{l}\text { and } \\
\text { risky } \\
\text { pension } \\
\text { fund }\end{array}$ & $\begin{array}{l}\text { Equity } \\
\text { returns }\end{array}$ & $\begin{array}{l}r^{x p}=r^{e} \\
\left(\lambda^{p f}=0\right)\end{array}$ & 0 & - & + & + & + \\
\hline Producti & & $g$ & 0 & 0 & + & + & + \\
\hline Particip & ion rate & $p$ & - & 0 & + & + & + \\
\hline Populati & n growth & $n$ & - & 0 & + & + & + \\
\hline Survival & & $\varepsilon$ & + & + & - & - & - \\
\hline
\end{tabular}

* A sufficient condition is $\left(1+r^{x c}\right)>(1+g)(1+n)$

** A sufficient condition is $\frac{1+r^{x p}}{1-\beta}<\left(1+r^{x c}\right)$ 
*** A sufficient condition is $\frac{1}{\theta}>1$

3.3 Asymmetric effects of the diversification of risks between pension funds and private savings

From Table 1 one can see that in our model the effects of changes in bond and equity returns on the economy are different depending on the investment strategy of pension funds and individuals.

When the pension fund only invests in bonds $\left(r^{x p}=r^{b}\right)$ and the savings are invested only in equities $\left(r^{x c}=r^{e}\right)$, an increase in bonds return decreases the pension contribution. Consumption and savings increase, because lifetime wealth increases as a result of the decreased pension contribution. A change in equity return does not affect the pension contribution. Given the sufficiency condition that $\frac{1}{\theta}>1$, an increase in equity return affects consumption in the young period negatively, and affects consumption in the old period and the savings positively. On the other hand, when savings are invested only in bonds $\left(r^{x c}=r^{b}\right)$ and the pension fund invests only in equities $\left(r^{x p}=r^{e}\right)$, the effects of bond returns are the same as the effects of an increase in equity returns, as discussed above, when savings are invested only in equities. The effects of equity returns are the same as the effects of an increase in the return on bonds, as we discussed above, when the pension fund invests only in bonds.

In reality, equity returns are more risky than bond returns. In Table 2 we show the asymmetric impact of a boom and a bust in the stock market on consumption of young and old. According to Table 2, with a second pillar investing in equities only and a third pillar investing in bonds, the response of the consumption of young and old to a boom and a bust in the stock market is the same. But in case of a reverse investment strategy the response of young and old to the boom and bust in the stock market is opposite. The intuition behind the results is, that when the second pillar is "risky" and the third pillar is "risk-free", the bust in the stock market increases the pension contribution according to equation (20). The increase in the pension contribution decreases both consumptions of young and old according to equations (22) and (23). When the third pillar is risky and the second pillar is risk-free, the recession in the stock market increases the consumption of young according to equation (22)., as consumers want to consume more when they are young and the return on savings is lower. 
Hence according to equation (23), the consumption of old decreases when the return on savings is lower.

Table 2

\begin{tabular}{|c|c|c|c|c|}
\hline $\begin{array}{l}\text { Pension } \\
\text { Fund }\end{array}$ & $\begin{array}{l}\text { Private } \\
\text { Savings }\end{array}$ & & $\operatorname{boom}\left(r^{e}-\right)$ & $\operatorname{recession}\left(r^{e} \downarrow\right)$ \\
\hline \multirow{2}{*}{ Risky } & \multirow{2}{*}{$\begin{array}{l}\text { Risk- } \\
\text { free }\end{array}$} & $c^{y}$ & increase & decrease \\
\hline & & $c^{o}$ & increase & decrease \\
\hline \multirow{2}{*}{$\begin{array}{l}\text { Risk- } \\
\text { free }\end{array}$} & \multirow{2}{*}{ Risky } & $c^{y}$ & decrease & increase \\
\hline & & $c^{o}$ & increase & decrease \\
\hline
\end{tabular}

3.4 The impact of the variance of the equity return

In the analysis of the steady state, we assume the equity return to be known. An interesting question arises when equity returns are risky, as they obviously are in reality, with an expected variance of $\sigma^{2}$. The variance of equity return affects the economy as we elaborate below for different investment strategies of the pension system.

When the pension fund invests in equity, $\left(W_{t}^{p}-\varepsilon N_{t-1} \eta_{t}^{p}\right)$ depends on the actual equity return and $\tau_{t}^{p}$ is stochastic. As a consequence one can derive from equation (21) that the variance of $\tau_{t}^{p}$ equals

$$
\begin{aligned}
& \operatorname{Var}\left(\tau_{t}^{p}\right)=\left[\frac{1+r_{t}^{p f}+\varphi}{\left(1+r_{t}^{p f}\right) N_{t} p_{t} w_{t}}\right]^{2} \operatorname{Var}\left(W_{t}^{p}\right)= \\
& {\left[\frac{1+r_{t}^{p f}+\varphi}{\left(1+r_{t}^{p f}\right) N_{t} p_{t} w_{t}}\right]^{2}\left(W_{t-1}^{p}+\tau_{t-1}^{p} N_{t-1} p_{t-1} w_{t-1}-\varepsilon N_{t-2} \eta_{t-1}^{p}\right)^{2} \sigma^{2}}
\end{aligned}
$$

It is obvious that the larger the variance of the equity return, the higher the variance of $\tau_{t}^{p}$ will be. According to equations (12), (13) and (14) the pension contribution affects consumption of both generations and savings. Therefore the variance of the equity return affects the consumption and savings indirectly through the pension contribution. 
Savings are also invested in equity. From equations (12), (13) and (14) one sees that the variance of the equity return has a direct impact on consumption of both generations and savings.

We expect the indirect effects of the variance of the equity return through the pension contribution on consumption of both generations and savings to be different from the direct effects through savings. But the precise impact in both scenarios is hard to derive analytically. These effects should be analysed using simulations - we leave that for further research.

\section{Simulations}

In this section we use simulations to analyse the dynamics of the model with values of the parameters which reflect the current state of the Dutch economy. For the simulations we use a continuous time version of the model presented in Du, Muysken and Sleijpen (2010, Appendix 22..$^{10}$ After presenting the baseline simulation in Section 4.1, we focus on the impact of the financial crisis in Section 4.2. We show that when the pension fund invests only in risky assets and savings are invested only in risk-free assets, consumption for both generations is lower when compared to a situation in which the pension fund invests only in risk-free assets and savings are invested only in risky assets. Moreover, the simulations enable us to track how the economy is affected over time. To analyse the opposite case we also simulate the impact of a boom in stock market in Section 4.3. Interestingly enough the effects are not consistently the opposite compared to the case of a negative shock, which is in line with our analysis in Section 3.3.

\subsection{The baseline simulation}

Most parameter values for the simulations are taken from the GAMMA model (CPB, 2007), which has been developed by the Central Planning Bureau to reflect the situation in the Netherlands. The output elasticity of capital stems from Groezen, Meijdam and Verbon (2007), reflecting the usual case, while the initial productivity, for reasons of simplicity, is chosen equal to unity. The real rate of return to capital is taken as the average of the corresponding rates of returns on bonds and equity. The ratio of the number young to the number of old is around 2 for the Netherlands. The PAYG and the pension fund benefits, as

\footnotetext{
${ }^{10}$ In Du, Muysken and Sleijpen (2010) we focused on three shocks - a stock market crash, inflation and an ageing population - which represent current economic (potential) problems.
} 
well as the part of the pension contribution paid by the firm, are chosen to reflect the Dutch situation. The resulting parameter values are presented in Table 3.

We calculate the steady state values of the variables of our model extending our model to continuous time which divides the young generation into 40 age-cohort and the old generation into 20 age-cohort, using the values of the parameters from Table 3 . The reason is that both the equity return and the bonds return are yearly results.

Table 3 The parameters values used in the simulations

\begin{tabular}{|ll|}
\hline Intertemporal substitution elasticity $(1 / \theta)^{*}$ & 0.5 \\
Time preference $(\rho)^{* 11}$ & $1.3 \%$ \\
Ratio of old to young** & 0.5 \\
Population growth rate $(n)$ & 0 \\
Participation rate $(p)^{*}$ & $78 \%$ \\
Initial productivity $(A)$ & 1 \\
Real productivity growth rate $(g)^{*}$ & $1.7 \%$ \\
Output elasticity of capital $(\alpha)$ & 0.3 \\
Real return on bonds $\left(r^{b}\right)^{*}$ & $2 \%$ \\
Real return on equity $\left(r^{e}\right)^{*}$ & $3.5 \%$ \\
Real return on capital $\left(r^{k}\right)$ & $2.75 \%$ \\
Inflation rate $(\pi)^{*}$ & $2 \%$ \\
PAYG benefit $\left(\xi^{g}\right)^{* *}$ & $30 \%$ \\
Pension fund benefit $\left(\xi^{p}\right)^{* *}$ & $50 \%$ \\
\hline $\begin{array}{l}\text { The part of the pension premium paid by the firm }(\beta) \\
\text { ( })\end{array}$ & 0.75 \\
\hline
\end{tabular}

Source CPB (2007)

**Source Bonenkamp et al.(2010)

\footnotetext{
${ }^{11}$ The rate of time preference is $1.3 \%$, this implies the discount factor $\gamma$ for different year is $1 /(1+$ $0.013)^{t-25}$ with $25 \leq t \leq 85$, individuals enter the economy at the age of 25 and die at 85 .
} 
The resulting values of the PAYG contribution rate, the pension contribution rate, the consumption of the young and the old and the savings are presented in Table 4. All values are expressed as a proportion of the wage the workers receive. In order to make the results comparable, we let consumption of young with a "risky" $\operatorname{second} \operatorname{pillar}\left(\lambda^{p f}=0\right)$ and "riskfree" third $\operatorname{pillar}\left(\lambda^{\text {cons }}=1\right)$ equal consumption of young with a "risky third" $\operatorname{pillar}\left(\lambda^{\text {cons }}=0\right)$ and "risk-free" second pillar $\left(\lambda^{p f}=1\right)$, by adjusting the pension fund benefits to $31.6 \%$ when the third pillar is "risky". Mind that the pension contribution rate is the total value paid by the worker and the firm. The workers, in our model, only need to pay $1 / 4$ of the total pension contribution rate. The resulting contribution rates for PAYG and for the pension funds are plausible (Bonenkamp et al., 2010). Both the consumption and the savings of the young reflect the average of the young generation. The consumption of the old reflects the average of the old generation.

From Table 4 it can be concluded, comparing the scenario when the pension fund is "risky" and savings are "risk-free" to the scenario when the pension fund is "risk-free" and savings are "risky", that the pension contribution is lower in the second scenario. The reason is that the pension benefit is smaller. Moreover, consumption of the old and savings are higher in the second scenario. The reason is that the return on savings is higher when savings are invested in equities.

Table 4 Steady-state values of the variables, relative to wage

\begin{tabular}{|c|l|l|l|l|l|l|}
\hline $\begin{array}{l}\text { Pension } \\
\text { Fund }\end{array}$ & $\begin{array}{l}\text { Private } \\
\text { Savings }\end{array}$ & $\begin{array}{l}\tau^{g} \\
\text { (PAYG } \\
\text { contribution } \\
\text { rate) }\end{array}$ & $\begin{array}{l}\tau^{p} \\
\text { (pension } \\
\text { contribution } \\
\text { rate) }\end{array}$ & $\begin{array}{l}c^{y} \\
\text { (consumption of } \\
\text { young) }\end{array}$ & $\begin{array}{l}c^{o} \\
\text { (consumption of } \\
\text { old) }\end{array}$ & $\begin{array}{l}s \\
\text { (savings) }\end{array}$ \\
\hline Risky & Risk-free & 0.15 & 0.1268 & 0.7725 & 0.6961 & 0.0545 \\
\hline Risk-free & Risky & 0.15 & 0.1135 & 0.7725 & 0.7421 & 0.1077 \\
\hline
\end{tabular}


We simulate a shock in the stock market in period 2, which makes the pension fund wealth fall by $15 \%$, in case the pension fund invests in equities. Moreover, it is assumed that the real return on equity permanently drops to $80 \%$ of its steady state value in the following periods. We also simulate the same shock in the stock market in case the pension fund invests in bonds only and individuals invest in equities.

Figures 1- 4 present the impact on the pension contribution rate, consumption of the young, consumption of the old and savings, expressed as a fraction of wage received when young. We compare the results of the simulation in both scenarios.

Figure 1 shows that when the pension fund invests in equity, the pension contribution rate increases strongly as a result of the shock, which seems plausible given the drop in pension wealth. This factor contributes to a fall in consumption of the young, as can be seen from Figure 2. Although the pension benefits are not affected by the stock market crash, the decrease in consumption of the old follows from the lower savings - compare Figures 3 and 4. The sharp decrease in savings observed in Figure 4 follows from the decline in life-time income due to the stock market crash, while the young want to maintain a certain level of consumption. When the pension fund is "risk-free", investing in bonds, the pension contribution rate is not affected by the stock market shock.

One sees from Figure 2 that the response of consumption of the young to the shock is different. When the second pillar is "risky", the sharp decrease in consumption of the young is due to the dramatic increase in the pension contribution rate. When the third pillar is "risky", the consumption of the young first increases, because the young decide to consume more, given of the much lower equity return they can get from savings. The decrease of the consumption of the young is due to the income effect of the decreased lifetime wealth dominating the substitution effect.

One sees from Figures 3 that the response of consumption of the old to the shock is larger when the third pillar is "risky": savings decrease more when they are invested in equity because of the stock market shock.

As can be seen from Figure 4, when the second pillar is "risky", savings decrease more at first, because the young have to pay a higher pension contribution rate. When the pension contribution rate decreases, savings increase.

Comparing Figures 2 and 3, we can conclude that consumption of both generations is lower in a situation in which the pension fund invests in equities compared to a situation in 
which the pension fund invests in bonds. These simulation results are consistent with what we show in the Table 2.

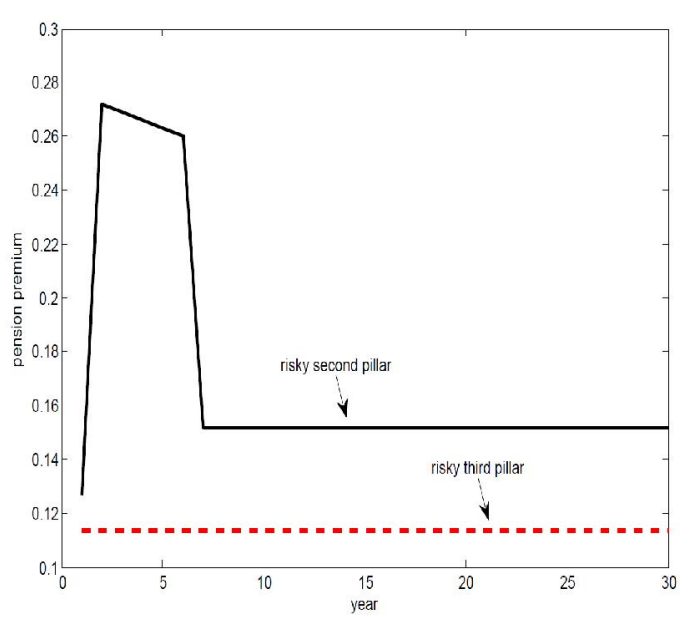

Figure 1 the adjustment path of pension contribution rate

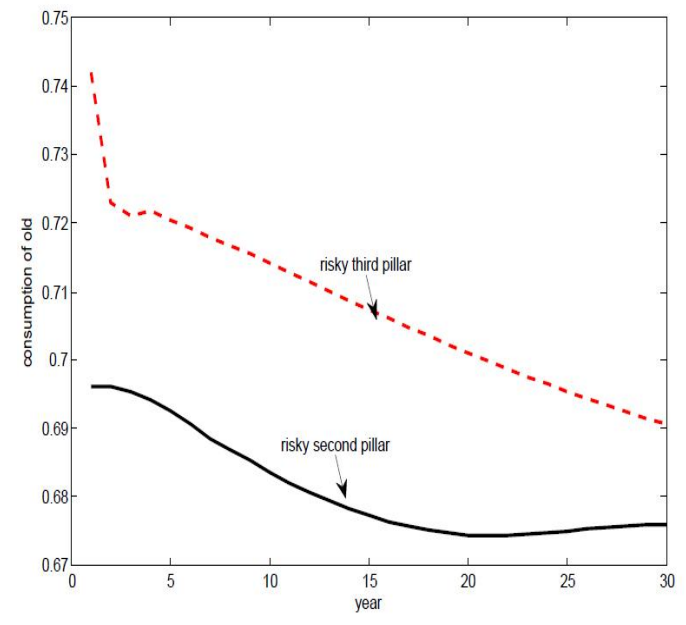

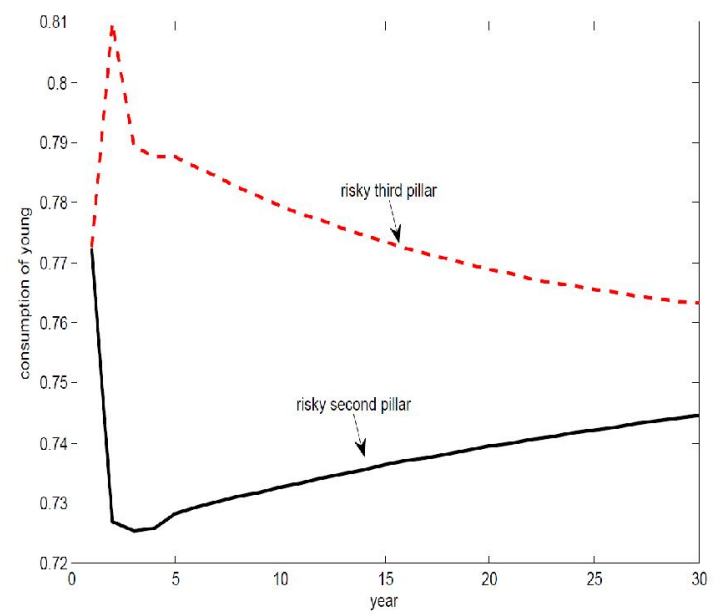

Figure 2 the adjustment path of consumption of young

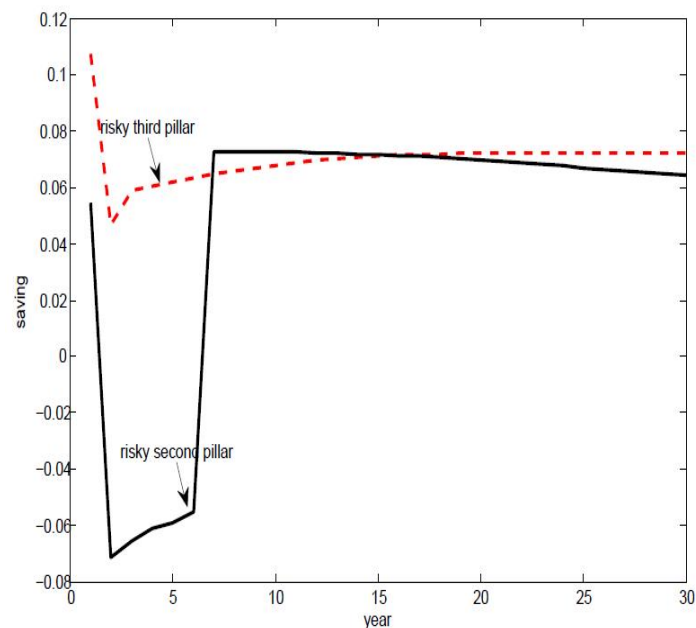

Figure 3 the adjustment path of consumption Figure 4 the adjustment path of saving of old

\subsection{A boom in the stock market}

We simulate a boom in the stock market in period 2, which makes the pension fund wealth increase by $15 \%$, in case the pension fund invests in equities, moreover, it is assumed that the real return on equity permanently increases to $120 \%$ of its steady state value in the following periods. We also simulate the same boom in the stock market, but with the pension fund investing only in bonds. 
Figures 5- 8 present the impact on the pension contribution rate, consumption of the young, consumption of the old and savings, expressed as a fraction of wage received when young. We compare the results of the simulation in both scenarios.

Figure 5 shows that when the pension fund is "risky", investing only in equity, the pension contribution rate decreases strongly as a result of the boom (pension contribution rate falls to zero, meaning contribution rate holidays), which seems plausible given the increase in pension wealth. This factor contributes to an increase in consumption of the young as can be seen from Figure 6. Although the pension benefits are not affected by the stock market boom, the increase in consumption of the old follows from the higher savings - compare Figures 7 and 8. The sharp increase in savings observed in Figure 8 follows from the increase in lifetime income due to the stock market boom. When the pension fund is "risk-free", investing only in bonds, the pension contribution rate is not affected by the stock market boom.

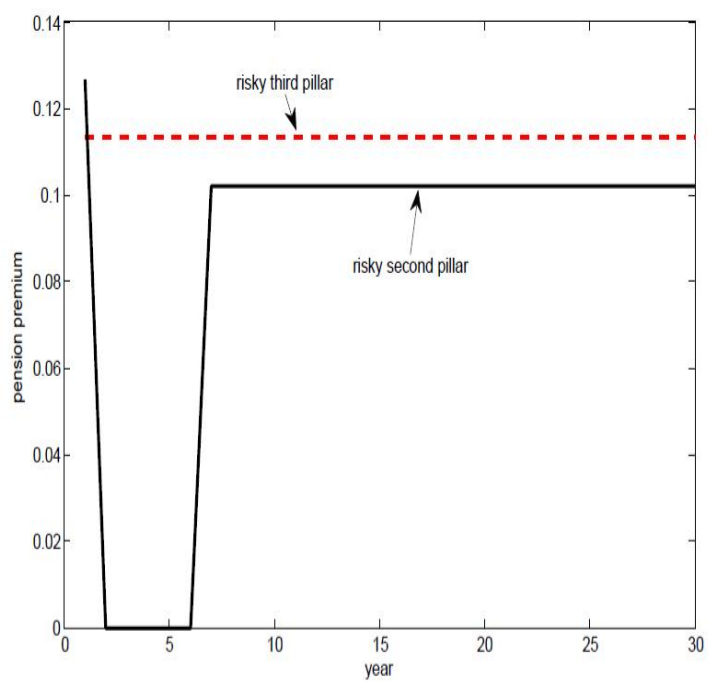

Figure 5 the adjustment path of pension contribution rate

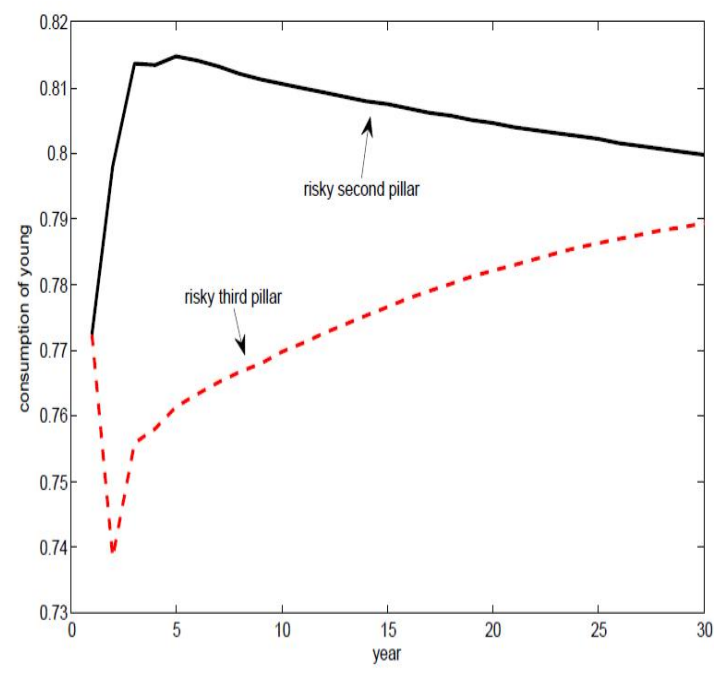

Figure 6 the adjustment path of consumption of young 


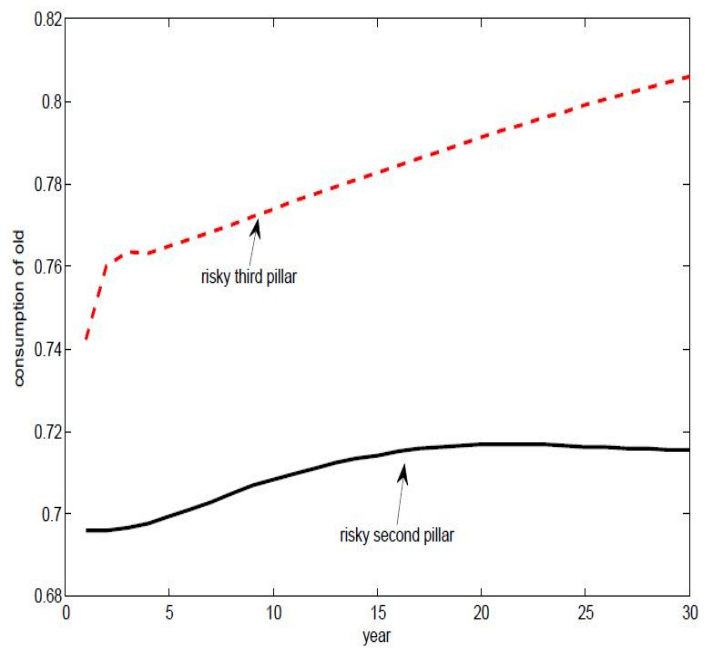

Figure 7 the adjustment path of consumption of old

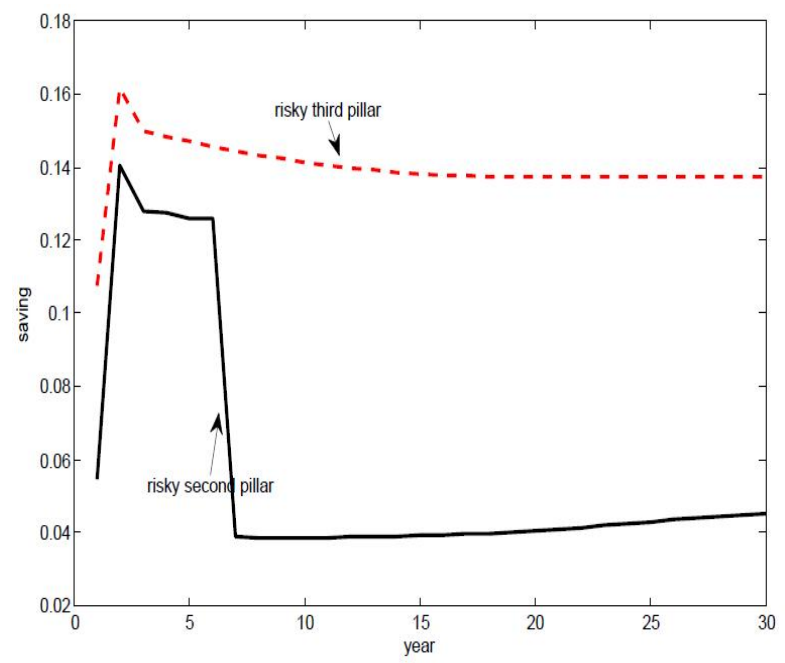

Figure 8 the adjustment path of saving

One sees from Figures 6 that the response of consumption of the young to the boom is different. When the second pillar is "risky", the sharp increase in consumption of the young is due to the dramatic decreased pension contribution rate. When the third pillar is "risky", the consumption of the young first decreases, as the substitution effect is larger because of the high equity return. Subsequently the consumption of the young increases as a result of the income effect dominating the substitution effect.

One sees from Figures 7 that the response of consumption of the old to the shock is larger when the third pillar is "risky": savings increase more when they are invested in equity because of the stock market boom.

As can be seen from Figure 8, when the second pillar is "risky", savings increase more because the young pay lower pension contribution rate. And when the pension contribution rate increases, the savings decrease.

Comparing Figure 6 and Figure 7, we can conclude that consumption of the old is lower in a situation in which the pension fund invests in equities compared to a situation in which the pension fund invests in bonds. The consumption of the young is higher in a situation in which the pension fund invests in equities compared to a situation in which the pension fund invests in bonds. These simulation results are consistent with what we show in the Table 2. 


\section{Concluding remarks}

In this paper, we analyse the impact of the financial crisis on a small open economy with a special focus on the pension system. We develop an overlapping generation model with a three-pillar pension system and defined benefits. The model allows us to derive the impact of shocks on the economy in an analytical way. We briefly examine how pension benefit ratios, returns on bonds and equity, the participation rate, the population growth rate, the survival rate, the inflation rate, productivity and the division of the pension contribution between the firms and the workers affect the consumption of the young and the old, as well as savings, in the steady state. However, the focus of our model is on the impact of the financial crisis, in particular in relation to the diversification of risks between funded pensions and private savings. We show that in case of a fall in equity returns consumption of both the young and the old generations is higher when pensions invest only in risk-free assets and private savings are invested only in risky assets, compared to a situation in which the opposite investment strategy is followed. Savings are higher too in the first scenario. An interesting observation is that in case of an increase in equity returns the opposite effect does not hold. Although consumption of the young is higher when the pension fund invests only in risky assets instead of risk-free assets, this does not necessarily hold for consumption of the old. The reason is that the equity returns affect the consumptions through different ways in the two different investment strategies as we discussed in Section 3.

The model presented in this paper allows us to study the interaction of the three pillars under different exogenous (economic) shocks. For this purpose, the impact of a stock market crash has been simulated for the case of The Netherlands. The simulation results clearly show that in the three-pillar system, the risk diversification between risk-free assets for pension funds and risky assets for savings have a relatively positive effect on consumption of both generations and on savings. As predicted, the opposite case does not hold uniformly for an increase in equity returns.

Both the model and the findings of our simulation support the notion that pension funds should always invest in relatively risk-free assets, while private savings then can be invested in more risky assets. That is an important lesson from the financial crisis. 


\section{REFERENCES}

Beetsma, M.W.J. and A. Lans,Bovenberg(2008) Pensions and Intergenerational Risk-sharing in General Equilibrium, Economica.

Bonenkamp, J., E. Westerhout en S.J. Vos (2010) Commissie Toekomstbestendigheid Aanvullende Pensioenregelingen, CPB Memorandum, 1/2010/01.

Burtless, G. (2010) Lessons of the Financial Crisis for the Design of National Pension Systems, Economic Studies, Vol. 56, 3/2010, 323-349

DNB (2010), Naar nieuwe pensioencontracten: Wat zijn de voorkeuren van de deelnemens?, Press publication, the Dutch Central Bank, 16 December 2010.

Du, C., J. Muysken and Sleijpen, O. (2010) Economy wide risk diversification in a threepillar pension system, METEOR Research Memorandum.

Dutta, J., S. Kapur and J.M. Orszag (2000) A Portfolio Approach to the Optimal Funding of Pensions, Economics Letters 69 (2000), 201-206.

Gollier, M. (2007) Intergenerational Risk-sharing and Risk-taking of A Pension Fund, CESIFO Working Paper, NO. 1969.

Groezen, B. , L. Meijdam and Verbon, H. (2007) The case for Pay-as-you-go pensions in a service economy, Scottish Journal of Policitical Economy, Vol. 54, No. 2.

Knell, M. (2010) The Optimal Mix Between Funded and Unfunded Pension Systems When People Care About Relative Consumption, Economica.

Miles, D. (2000) Funded and Unfunded Pension Schemes: Risk, Return and Welfare, CESifo Working Paper Series, No. 239.

Matsen, E. and I. ThHgersen (2004) Designing Social Security- A Portfolio Choice Approach, European Economic Review, 48 (2004), 883 - 904.

Maurer, R., O.S. Mitchell and R. Rogalla (2009) Managing Contribution and Capital Market Risk in A Funded Public Defined Benefit Plan: Impact of CVaR Cost Constraints, Insurance: Mathematics and Economics, 45 (2009), 25-34. 